\title{
The Framing of Climate-Change Discourse by Shell and the Framing of Shell's Climate Change-Related Activities by The Economist and The Financial Times
}

\author{
Oleksandr Kapranov
}

\section{Introduction}

This article involves a qualitative framing analysis of Shell's climate change discourse and how Shell's climate change-related activities are framed by the leading British financial newspapers. The present publication offers a novel research facet by focusing on Shell's framing of its climate change discourse in the $2014 \mathrm{AR}$ and on The Economist's and The FT's reporting of Shell's climate change-related activities in 2014.

The article is structured as follows: first, previous studies of the press coverages of Shell's environmental and climate change-related activities will be presented. Second, the frames associated with climate-change discourse will be identified in Shell's 2014 AR and subsequently juxtaposed with the to-be-identified frames associated with Shell's climate changerelated activities as reported by The Economist and The FT, respectively.

1.1. Previous research involving the framing of Shell's climate change-related activities reported by the British press

In general terms, framing as a concept is considered to be concerned with the construction of meaning (Browne et al. 2017, 11). According to Dahl (2017), "the notion of framing concerns how individuals and groups organize, perceive, and communicate about the world" (Dahl, 2017, 22). As indicated by Levin and his colleagues (1998), frames refer to those specific organising principles that are socially shared, relatively stable over 
time, and symbolically meaningful. At both the macro and micro levels of discourse, framing is assumed to provide specific problem definitions, causes, and possible solutions in meaning construction, information processing, and decision making (Entman 2004; Nisbet et al. 2013). Echoing Entman (2004), Wasike $(2017,180)$ posits that framing involves the emphasis of certain aspects of reality with the intention of promoting a particular definition, interpretation or evaluation.

Framing as a research methodology has been successfully applied to a range of disciplines as an analytical framework (Kapranov 2016), involving media studies and media discourse. Nisbet (2009) suggests that frames are storylines, which aim at communicating why an issue might be a problem, who or what might be responsible for it, and what should be done about it. In accordance with Fløttum \& Gjerstad (2017, 2), framing "corresponds to the process which implies a strategic selection (conscious or not) of language features for a particular purpose." To further specify the notion of frame and framing in discourse, it should be noted that

The repetitive use of a framing builds familiarity and allows for certain assumptions or theories to be left unstated, reducing the complexity of the issue being reported. Through deploying frames, certain viewpoints will be emphasised while others may be sidelined. For example, particular words, metaphors or images may be used repeatedly, rendering certain ideas or viewpoints more salient or memorable and others less (or in-) visible. (Naylor et al. 2017, 6)

The notion of framing is applicable to political discourse, as well as discourse involving environmental and climate change-related issues (Nisbet et al. 2013). The framing of climate-change discourse in the media refers to how mass media highlight the issue of climate change to make it memorable for their audiences (Nwabueze \& Egbra 2016). There is a substantial collection of previous studies, which elucidate the framing of climate change by the media (Boykoff \& Boykoff 2007; Carvalho 2010; Crist 2007; Jensen 2003; Nwabueze \& Egbra 2016). Previous research indicates that the British press frames a variety of environmental and climate change-related issues as a polyphonic discursive space (Carvalho 2010). This space is characterised by a polyphony of voices including multiple actors; for example, the British government, the cor- 
porate world, the general public, and research community. The framing of climate change by the British press is comprised of the above-mentioned polyphonic voices, involving scientific research, political debates and ethical considerations (Dahl \& Fløttum 2014). It is inferred from previous research findings that the British press, as an authorised voice, exerts important influence over the public perception of climate change (Boykoff \& Boykoff 2007; Crist 2007).

A meta-analysis of previous scholarship suggests that the framing of Shell's climate change-related activities by the British press appears to be well represented (Bakir 2006; Carvalho 2010; Jensen 2003; Kruse 2001; O’Neill 2013; Tsukas 1999). Previous research (Jensen 2003) indicates that one of the salient framings of Shell's climate-change practices by the British press involves the concept of citizenship. This concept is predominantly associated with the Shell-owned Brent Spar platform. In response to the Brent Spar accident, ordinary citizens in several European countries (the UK, the Netherlands, Denmark and Germany) have succeeded, by means of the consumer boycott, in forcing Shell to relinquish its plans to sink the Brent Spar oil platform in the North Atlantic. Jensen (2003) suggests that the British press framed the Brent Spar accident by the concept of a citizen who influences Shell's environmental agenda.

Another salient framing of Shell's environmental and climate changerelated activities was construed by the British press employing the frames of 'Battle', 'Dominance', and 'War' (Jensen 2003). Specifically, Shell's plans to submerge the Brent Spar platform in the Atlantic were framed by the British press as a 'War' frame. The framing centred on narratives involving the threat to the environment and the consumers (Kruse 2001). Jensen $(2003,76)$ indicates that the British press framed Shell as a perpetrator of environmental crime, who wages a war on the environment, whilst Greenpeace enjoys positive coverage as the climate-change problem-solver.

Like Jensen (2003), Bakir (2006) argues that the British press frames Shell via the concepts of battle and war, respectively. This framing evokes a biblical reference to Goliath and involves "a series of 'sight-bites' with David-and-Goliath connotations, portraying the unevenness of the battle with the world's then largest non-state oil company" (Bakir 2006, 684). Specifically, "Greenpeace's victory over Shell was widely depicted in the UK and German press as a modern-day victory of David over Goliath" 
(Tsukas 1999, 516). Previous scholarship seems to support, therefore, the contention that the framing of the Brent Spar incident by the British press was construed by the discursive means associated with battles, dominance, and wars (Bakir 2006; Jensen 2003).

It is inferred from previous research that the press seems to ascribe the role of villain or perpetrator to the multinational fossil-fuels corporations seen to be responsible for the negative consequences of climate change (Crist 2007; Swyngedouw 2010). In this regard, Crist (2007) argues that "the dominant framing of climate change-its identification as the most urgent problem that we face-all but bluntly declares that the sky is falling" (Crist 2007, 46). Echoing Crist (2007), Swyngedouw (2010) notes that the framing of fossil-fuels corporations in the British press, amongst others Shell, is embedded in the apocalyptic imaginary of the climate-change debate. Based upon these findings, it is possible to assume that the British press generally frames Shell's environmental and climate change-related activities employing Biblical, war-related and protest imagery (Crist 2007; Jensen 2003; Kruse 2001; O’Neill 2013; Tsukas 1999).

However, current literature does not appear to provide an account of how Shell's climate change-related discourse is framed by the British financial press. In particular, there are no comprehensive research data on the coverage of Shell's climate change-related activities by the leading financial newspapers in the UK, such as The Economist and The FT. Furthermore, there are open questions regarding, for instance, the juxtaposition of Shell's framing of climate-change discourse with the framing of Shell's climate change-related activities by the British financial press. These and other pertinent questions are further addressed and examined in this article.

\section{Hypothesis and specific research aims}

Based upon previous research findings (Bakir 2006; Carvalho 2010; Crist 2007; Jensen 2003; Kruse 2001; O’Neill 2013; Swyngedouw 2010; Tsukas 1999), it was assumed in the hypothesis that the British financial press would frame Shell's climate change-related activities employing Biblical, war-related and protest imagery. Also based on previous research (Livesey 2001; Mirvies 2000), it was assumed that Shell's corporate discursive space would generally frame climate change by the concept of 
care, in contrast to the imagery in the British financial press. Hence, the following specific research aims were formulated: i) to identify the framing of Shell's climate change-related activities by The Economist and The FT; ii) to identify the framing of climate change discourse by Shell in the 2014 Shell AR and subsequently juxtapose the framing with that of The Economist and The FT.

\section{Materials}

The present study analysed the following materials: i) Shell's 2014 AR available at www.shell.com; and ii) articles about Shell's climate changeactivities published in 2014 editions of The Economist and The FT available online at www.economist.com and www.ft.com. The choice of The Economist and The FT was motived by the following considerations: First, both The Economist and The FT position themselves as serious financial papers. Second, The Economist and The FT target similar readerships, comprised of business and financial leaders, government officials, and corporate executives. Third, The Economist and The FT are associated with the free market economy and deemed to be close to the international corporations. Fourth, the economics journalism in The Economist and The FT involved a register of socio-economic discourse that was suited to both specialist and non-specialist audiences (Boykoff \& Boykoff 2007; O’Neill 2013).

\section{Table 1: Descriptive statistics of the corpus}

\begin{tabular}{|c|c|c|c|c|}
\hline \# & Article/AR & Title & $\begin{array}{l}\text { Number } \\
\text { of Words }\end{array}$ & $\begin{array}{l}\text { Date of } \\
\text { Publication }\end{array}$ \\
\hline 1 & $\begin{array}{l}\text { The } 2014 \text { Shell } \\
\text { Annual Report }\end{array}$ & Chairman's Message, 6 & 962 & 11.03 .2015 \\
\hline 2 & $\begin{array}{l}\text { The } 2014 \text { Shell } \\
\text { Annual Report }\end{array}$ & Chief Executive Officer's Review, 7-8 & 1213 & 11.03 .2015 \\
\hline 3 & $\begin{array}{l}\text { The } 2014 \text { Shell } \\
\text { Annual Report }\end{array}$ & Environment and Society, 52-56 & 5119 & 11.03 .2015 \\
\hline 4 & The Economist & $\begin{array}{l}\text { Childish arguments: Greenpeace, Lego and } \\
\text { Shell }\end{array}$ & 562 & 17.10. 2014 \\
\hline 5 & The FT & $\begin{array}{l}\text { Oil majors' RQD into conventional and } \\
\text { renewable energy at risk }\end{array}$ & 1263 & 25.09 .2014 \\
\hline 6 & The FT & $\begin{array}{l}\text { Monopoly is a bureaucrat's friend but a } \\
\text { democrat's foe }\end{array}$ & 922 & 12.08 .2014 \\
\hline
\end{tabular}




$\begin{array}{lllll}7 & \text { The FT } & \text { Scotland after the vote: investments } & 1316 & 12.09 .2014 \\ 8 & \text { The FT } & \text { Raízen to spend \$1bn on ethanol boost } & 481 & 28.12 .2014 \\ 9 & \text { The FT } & \text { SNC-Lavalin agrees } £ 1.16 \text { bn offer for Kentz } & 622 & 23.06 .2014\end{array}$

\section{Methods}

The methodological framework employed in the study was based upon the guidelines proposed by Shehata and Hopmann (2012) in their research involving climate-change discourse. In accordance with Shehata and Hopmann $(2012,183)$, the climate-change frame was coded as present whenever a paragraph mentioned i) human activity as a cause of global warming; ii) emission reduction as a way of combating climate change; iii) natural variations as a cause of global warming; iv) climate science/knowledge regarding the extent or causes of global warming; v) the economic consequences of climate change-related activities and legislation in general economic terms or in terms of numbers.

In the present study, the corpus of online publications in Shell's 2014 $\mathrm{AR}$, The Economist, and The FT was searched electronically for the keywords climate change, Shell, Shell corporation, environment, The Kyoto Protocol, carbon capture, environmental pollution, fossil fuels corporation, and then manually coded and analysed in accordance with the abovementioned methodology developed by Shehata and Hopmann (2012).

\section{Results and discussion}

Data analysis yielded the results presented in Table 2. The table includes a number of frames associated with the climate-change discourse in Shell's $2014 \mathrm{AR}$ and in the corpus of The Economist and The FT, respectively.

Table 2. The Framing of Climate-Change Discourse in the 2014 AR by Shell, and the Framing of Shell's Climate Change-Related Activities by The Economist and The FT

\begin{tabular}{llll} 
Frame & Shell & The Economist & The FT \\
\hline Battle & yes & no & no \\
Care & yes & no & no \\
Immoral Corporation & no & yes & no \\
Money & yes & no & yes \\
Research and Development & yes & no & yes \\
Responsible Citizen & yes & no & no \\
Sinner & no & yes & no
\end{tabular}


The results of the data analysis indicate that, in 2014, The Economist and The FT employ different sets of frames in their discussion of Shell's climate change-related activities. Specifically, The Economist frames the activities using the frames 'Immoral Corporation' and 'Sinner', while The FT employs the frames 'Research and Development', and 'Money'. As evident from Table 2, Shell frames its climate-change discourse in 2014 using the following frames: 'Battle', 'Care', 'Research and Development', 'Money', and 'Responsible Citizen'.

\subsection{The frames 'Immoral Corporation' and 'Sinner'}

It should be mentioned that the computer search for the key words mentioned in the methods section yielded only one text by The Economist in the year of 2014 pertaining to Shell's climate-change activities. In that text, The Economist frames Shell as a multinational corporation with no feelings and no morals in the frame 'Immoral Corporation' (The Economist 2014):

(1) If Shell comes to fear that drilling in artic waters will damage its brand and encourage other well-regarded companies to distance themselves from it, that may help dissuade it from further drilling. Worries about 'stigmatisation' belong in discussions of people with HIV, not in debates over corporations. Oil majors do not have feelings and cannot be morally injured. (The Economist 2014)

This framing is in contrast with Shell's framing with reference to responsibility and care, as identified in the 2014 AR by Shell (Shell 2015). Furthermore, The Economist frames Shell as a sinner, who plans to drill in the Arctic. However, the frame 'Sinner' in The Economist appears to involve all users of fossil fuels, as evident in Excerpt 2:

(2) [...] we are all sinners: In our driving, flying and phone-charging, in the buildings we work and in the homes we heat, we are all implicated in the use of fossil fuel. (The Economist 2014)

These findings support previous research (Bakir 2005; Doulton \& Brown 2009; O'Neill 2013; Tsukas 1999), which indicates that the British press seems to frame Shell in terms of Biblical and moral themes. Arguably, the 
framing of Shell via the frame 'Sinner' has religious implications, since The Economist simultaneously employs the concepts of morality and sin in the framing illustrated by Excerpt 2. In this regard, The Economist data are evocative of religious and biblical imagery of climate change reported in previous research by Bakir (2006) and Tsukas (1999).

\subsection{The frames 'Research and Development' and 'Money'}

In contrast to The Economist (2014), The FT frames Shell's climate changerelated activities in 2014 using the frames 'Research and Development' and 'Money', respectively. It should be noted that these frames are embedded into a generally positive framing of Shell by The FT. Shell's positive, or at least neutral-positive, image is framed by The FT by referring to Shell as a household name; for example, "Large companies are all around us. We buy our mid-morning coffee from global brands such as Starbucks, use petrol from Exxon or Shell [...]" (The FT 2014). Data analysis indicates that The FT frames Shell i) as a significant corporate actor, e.g. "Large energy and industrial groups such as Shell and BP [...]" (The FT 2014); and ii) as a corporation popular with the investors, e.g. "Companies such as GlaxoSmithKline, Royal Dutch Shell and BP-whose shares are popular with retail investors [...]" (The FT 2014).

Set against this positive background, the present data suggest that The FT frames Shell's climate-change discourse within the frame 'Research and Development'. The FT indicates that "Shell and Total are also the two big oil companies that have the greatest interests in renewable energy, including biofuels and solar power" (The FT 2014). The FT acknowledges Shell's interest in renewable energy and indicates that Shell invests in research and development (R\&D) of new technologies, which mitigate the negative consequences of climate change. The framing of Shell's activities in 2014 via the frame 'Research and Development' is evident in Excerpt 3:

(3) $R \nLeftarrow D$ spending gives a sense of where companies are placing their bets. Shell and Chevron cut their spending sharply during the downturn, and have since been reviving it. [...] The increased spending appears to be showing results: Shell was granted 189 US patents last year, up from 127 in $2011 \ldots$ Shell's patents have more significance for the industry than its competitors. Gerald Schotman, Shell's executive vice-president of $R \& D$, says [...] it [is] more important for the produc- 
tion companies to develop their own technological strength [...]. (The FT 2014)

The frame 'Research and Development' has been identified in the 2014 AR by Shell; for example, "We are also investing in research to help devel$o p$ and commercialise advanced biofuels" (Shell 2015, 54). Judging from the data, this frame is concurrent with another frame, 'Money', associated with the investments in new energy sources to limit carbon emissions; for example:

(4) Shell plans to continue to invest in innovative technology, talented people and the development of new energy sources that will be vital to meet rising long-term demand, while limiting carbon emissions. (Shell 2015, 6)

Like Shell, The FT appears to frame Shell's climate change mitigation by the frame 'Money', as seen in (5):

(5) Raizen, Royal Dutch Shell's joint venture in Brazil, plans to spend close to 1 bn on 'second generation' ethanol plants over the next decade, in one of the boldest investments yet in biofuel production from sugar cane waste. [...] For producers such as Raizen, the result of a 2010 tie-up between Shell and Brazil's Cosan, it also promises to boost productivity, and, potentially, profits. (The FT 2014)

Both (4) and (5) reveal that Shell and The FT embed the frame 'Money' into the narrative of the costs and investments that are associated with climate change. The results of the data analysis indicate that Shell frames its climate-change discourse in relation to profits, financial losses and additional expenses incurred from the negative consequences of climate change, e.g. "We already assess potential costs associated with $\mathrm{CO}_{2}$ emissions when evaluating projects. However, in future, governments may increasingly impose a price on $\mathrm{CO}_{2}$ emissions that relevant companies will have to incorporate in their investment plans" (Shell 2015, 52). By framing its climate-change discourse via 'Money', Shell emphasises that climate change may involve additional costs: 
(6) Rising climate change concerns could lead to additional regulatory measures that may result in project delays and higher costs. [...] Over time, we expect that a growing share of our $\mathrm{CO}_{2}$ emissions will be subject to regulation and result in increasing our costs. (Shell 2015, 12)

Another aspect of the frame 'Money' is evident in Shell's narrative of itself as a social and moral corporation, a claim which mitigates the negative consequences of climate change by creating 'green' profit-generating technologies and production facilities. This facet of the frame 'Money' is evident in Shell's willingness to introduce environmentally friendly natural gas-based technologies, e.g. "Effective carbon-pricing systems are needed. They can drive a shift from coal- to gas-fired power generation [...]" (Shell 2015, 8). This finding is evocative of the earlier contention that Shell's climate-change discourse involves sustainable development, which refers to "a complex notion that seeks to reconcile the goals of economic development and ecological wellbeing" (Livesey 2002,315 ).

\subsection{The frames 'Battle', 'Responsible Citizen', and 'Care'}

Shell's framing of the climate-change discourse is associated with the concepts of battle, citizenship and care, which have not been identified in the 2014 data from The Economist and The FT. In the 2014 AR, the frame 'Battle' is foregrounded by placing it in the initial position of the report, in the section titled Strategic Report. The Chairman's Message. In this opening section, Shell presents itself as a responsible and climate change-aware corporation, which engages in climate-change mitigation:

(7) All sectors of society must work together to combat climate change effectively [...]. (Shell 2015, 6)

It should be observed that the frame 'Battle' feeds back into the frame 'Responsible Citizen' with its discursive space of corporate citizenship and corporate responsibility, e.g. "All sectors of society must work together [...]" (Shell 2015, 6). These findings are in concert with Livesey (2002), who indicates that corporate citizenship is a typical feature of Shell's post-Brent Spar discourse related to the environment and climate change. In the $2014 \mathrm{AR}$, Shell frames its climate-change discourse via the frame 'Responsible Citizen': 
(8) Our success in business depends on our ability to meet a range of environmental and social challenges. We must show we can operate safely and manage the effect our activities can have on neighbouring communities and society as a whole. (Shell 2015, 52)

Shell's corporate responsibility is framed by foregrounding the concepts of society and community, as well as by the concept of inclusion, which is expressed in the recurring personal pronouns in the third person plural; for instance our success, our ability, our activities. These pronouns are micro-contextually related to the noun phrases neighbouring communities and society as a whole to frame Shell as an integral part of the community it operates in.

Arguably, the idea of corporate citizenship is concurrent with Shell's framing of its climate-change activities via the frame 'Care', where 'Care' is regarded as creating, helping, and sharing; e.g. "to better share the benefits of our activities, such as creating new jobs and help develop local economies" (Shell 2015, 56). The co-occurrence of the frames 'Care' and 'Responsible Citizen' is evident in the context of Shell's acknowledgement of the potential negative impacts associated with fossil fuels, as in the following quote:

(9) We also work with communities, business partners, non-governmental organisations and other bodies to address potential impacts and share the benefits of our operations and projects. (Shell 2015, 52)

In (9), Shell addresses the issue of climate change concurrently with social and environmental topics (Shell 2015). Shell's self-image as a good climate-change-concerned citizen is facilitated and reinforced by the imagery of care, thus resulting in the framing of Shell as both a responsible and a caring citizen. Arguably, the frames of care and responsibility are employed in Shell's corporate discourse to frame Shell as a trustworthy, law-abiding citizen who is committed to sustainable development and is concerned about the issue of climate change.

The frame 'Care' is not novel in Shell's corporate discourse. Its presence has been discussed by Livesey (2002). Thus, the present data support previous research (Livesey 2001; Livesey 2002; Livesey \& Kearins 2002), which argues that Shell presents a self-mage of a caring corpora- 
tion in the matters of environmental sustainability, social responsibility and climate change. Shell's self-image as a caring corporation is part of the corporate strategy to maintain visibility and responsibility. Like other fossil-fuels corporations, Shell's corporate self-image is a significant factor in defining the company's identity.

\section{Conclusions}

This article presents a framing analysis of the climate-change discourse in the 2014 AR by Shell, which is juxtaposed with the framing of Shell's climate change-related activities in The Economist and The FT. The results of the framing analysis indicate that, in 2014, Shell frames its climatechange discourse via the frames 'Battle', 'Responsible Citizen', 'Care', 'Research and Development', and 'Money'. In contrast, The Economist frames Shell's climate-change activities in 2014 via the frames 'Immoral Corporation' and 'Sinner'. They evoke biblical and religious imagery and de-emphasise the concrete climate-change mitigating measures found in Shell's 2014 AR. On the other hand, this moral framing is absent in The FT's representations of Shell's climate-change activities in 2014. Specifically, The FT frames Shell's climate-change agenda employing the frames 'Research and Development' and 'Money'. Judging from these findings, it can be concluded that The FT's framing of Shell's climatechange activities in 2014 partially coincide with the Shell's self-image with regard to the issue climate change. The present findings indicate that, while The Economist and The FT share a similar corporate readership, their framing of Shell's climate change-related activities in 2014 are qualitatively different. ${ }^{1}$

\section{References}

Bakir, Vian. 2005. "Greenpeace v. Shell: Media Exploitation and the Social Amplification of Risk Framework (SARF)." Journal of Risk Research 8 (7-8):679-91.

Bakir, Vian. 2006. "Policy Agenda Setting and Risk Communication Greenpeace, Shell, and Issues of Trust." The Harvard International Journal of Press/Politics 11 (3):67-88.

1 Acknowledgement: I acknowledge funding from the Norwegian Research Council and from the University of Bergen within the framework of LINGCLIM project (grant $\mathrm{N} 220654)$. 
Boykoff, Maxwell T., and Jules M. Boykoff. 2007. "Climate Change and Journalistic Norms: A Case-Study of US Mass-Media Coverage," Geoforum 38 (6):1190-1204.

Browne, Jennifer, Evelyne de Leeuw, Deborah Gleeson, Karen Adams, Petah Atkinson, Rick Hayes. 2017. "A Network Approach to Policy Framing: A Case Study of the National Aboriginal and Torres Strait Islander Health Plan.” Social Science \& Medicine 172:10-18.

Carvalho, Anabela. 2010. "Media (Ted) Discourses and Climate Change: A Focus on Political Subjectivity and (Dis)engagement." Wiley Interdisciplinary Reviews: Climate Change 1 (2):172-79.

Crist, Eileen. 2007. "Beyond the Climate Crisis: A Critique of Climate Change Discourse." Telos 141:29-55.

Dahl, Trine. 2017. "Verbal and Visual Framing Activity in Climate Change Discourse: Media Representations of the IPCC's 5 th Assessment Report." In The Role of Language in the Climate Change Debate, edited by Kjersti Fløttum, 20-31. London/NY: Routledge.

Doulton, Hugh, and Katrina Brown. 2009. "Ten Years to Prevent Catastrophe? Discourses of Climate Change and International Development in the UK Press." Global Environmental Change 19 (2):191-202. Eubanks, Philip. 2005. "'Globalization', 'Corporate Rule', and Blended Worlds: A Conceptual-Rhetorical Analysis of Metaphor, Metonymy, and Conceptual Blending." Metaphor and Symbol 20 (3):173-97.

Fløttum, Kjersti, and Trine Dahl. 2014. "IPCC Communicative Practices: A Linguistic Comparison of the Summary for Policymakers 2007 and 2013." Text \& Talk 34 (4):401-20.

Fløttum, Kjersti, and Øyvind Gjerstad. 2017. "Narratives in Climate Change Discourse." WIREs Climate Change 8:1-15.

Jensen, Hans Rask. 2003. "Staging Political Consumption: A Discourse Analysis of the Brent Spar Conflict as Recast by the Danish Mass Media." Journal of Retailing and Consumer Services 10 (2):71-80.

Kampf, Constance. 2007. "Corporate Social Responsibility: WalMart, Maersk and the Cultural Bounds of Representation in Corporate Web Sites." Corporate Communications: An International Journal 12 (1):41-57.

Kapranov, Oleksandr. 2016. "The Framing of Serbia's Eu Accession by the British Foreign Office on Twitter.” Tekst i Dyskurs-Text und Diskurs 9:67-8o. 
Kruse, Julia. 2001. "Fantasy Themes and Rhetorical Visions in the Brent Spar Crisis: A Comparative Analysis of German and French Newspaper Coverage." Argumentation 15 (4):439-56.

Levin, Irwin P., Sandra L. Schneider, and Gary J. Gaeth. 1998. "All Frames are not Created Equal: A Typology and Critical Analysis of Framing Effects." Organizational Behaviour and Human Decision Processes 76 (2):149-88.

Livesey, Sharon M. 2001. "Eco-Identity as Discursive Struggle: Royal Dutch/Shell, Brent Spar, and Nigeria." Journal of Business Communication $38(1): 58-91$.

Livesey, Sharon M. 2002. "The Discourse of the Middle Ground Citizen Shell Commits to Sustainable Development." Management Communication Quarterly 15 (3):313-49.

Livesey, Sharon M., and Kate Kearins. 2002. "Transparent and Caring Corporations? A Study of Sustainability Reports by The Body Shop and Royal Dutch/Shell." Organization \& Environment 15 (3):233-58.

Mirvis, Philip H. 2000 . "Transformation at Shell: Commerce and Citizenship." Business and Society Review 105 (1):63-84.

Naylor, Rhiannon, Will Manley, Damian Maye, Gareth Enticott, Brian Ilbery and Alice Hamilton-Webb. 2017. "The Framing of Public Knowledge Controversies in the Media: A Comparative Analysis of the Portrayal of Badger Vaccination in the English National, Regional and Farming Press." Sociologia Ruralis 57 (1):3-22.

Nisbet, Erik C., P.S. Hart, Teresa Myers, and Morgan Ellithorpe. 2013. "Attitude Change in Competitive Framing Environments? Open-/ Closed-Mindedness, Framing Effects, and Climate Change." Journal of Communication 63:766-85.

Nisbet, Matthew C. 2009. "Communicating Climate Change: Why Frames Matter for Public Engagement." Environmental Science Policy Sustainable Development 51:12-23.

Nwabueze, Chinenye and Stella Egbra. 2016. "Newspaper Framing of Climate Change in Nigeria and Ghana." Applied Environmental Education \& Communication 15 (2):111-24.

O’Neill, Saffron J. 2013. "Image Matters: Climate Change Imagery in US, UK and Australian Newspapers." Geoforum 49:10-19.

Shehata, Andreas and Hopmann, D.N. 2012. "Framing Climate Change." Journalism Studies, 13 (2):175-92. 
Shell. 2015. "The 2014 Annual Report." http://reports.shell.com/annualreport/2014/.../entire_shell_ar14.pdf (accessed 1 January 2016).

Swyngedouw, Erik. 2010. "Apocalypse Forever? Post-political Populism and the Spectre of Climate Change." Theory Culture Society 27:213-32.

The Economist. 2014. "Greenpeace, Lego and Shell. Childish arguments." http://www.economist.com/blogs/democracyinamerica/2014/10/ greenpeace-lego-and-shell (accessed 1 January 2016).

The FT. 2014. "Oil Majors' ReD into Conventional and Renewable Energy at Risk." https://www.ft.com/content/c69618ao-4050-11e4-a343 - 00144 feabdco (accessed 1 January 2016).

The FT. 2014. "Monopoly is a Bureaucrat's Friend but a Democrat's Foe." https://www.ft.com/content/b62b46cc-216d-11e4-b145-00144feabdco (accessed 1 January 2016).

The FT. 2014. "Scotland After the Vote: Investments." https://www. ft.com/content/edb5224e-38fo-11e4-9526-o0144feabdco (accessed 1 January 2016).

The FT. 2014. "Raízen to Spend \$1bn on Ethanol Boost." https://www. ft.com/content/f585bbco-8a33-11e4-9b5f-oo144feabdco (accessed 1 January 2016).

The FT. 2014. "SNC-Lavalin Agrees $£ 1.16$ bn Offer for Kentz." https:// www.ft.com/content/421d3co6-fac9-11e3-8993-00144feab7de (accessed 1 January 2016).

Tsoukas, Haridimos. 1999. "David and Goliath in the Risk Society: Making Sense of the Conflict Between Shell and Greenpeace in the North Sea." Organization 6 (3):499-528.

Wasike, Ben. 2017. "Persuasion in 140 Characters: Testing Issue Framing, Persuasion and Credibility via Twitter and Online News Articles in the Gun Control Debate." Computers in Human Behavior 66:179-9o. 
